\title{
Antitumor activity and macrophage nitric oxide producing action of medicinal herb, Crassocephalum crepidioides
}

\author{
Koh Tomimori ${ }^{1,2 \dagger}$, Shinji Nakama ${ }^{1,3 \dagger}$, Ryuichiro Kimura ${ }^{1,4}$, Kazumi Tamaki ${ }^{1}$, Chie Ishikawa ${ }^{1,4}$ and Naoki Mori ${ }^{{ }^{*}}$
}

\begin{abstract}
Background: Crassocephalum crepidioides, a plant distributed in Okinawa Islands, is known in folk medicine; however, its anticancer activity has not been investigated. The aim of this study was to determine the in vitro and in vivo antitumor activities of C. crepidioides on murine Sarcoma 180 (S-180) and related molecular mechanisms.

Methods: The antitumor effect of C. crepidioides was evaluated in S-180-cell-bearing mice. Cell growth was assessed using a colorimetric assay. Nitrite and nitrate levels were measured by colorimetry. The expression levels of inducible NO synthase (iNOS) in murine RAW264.7 macrophages was assessed by reverse transcriptase-polymerase chain reaction. Activation of iNOS promoter was detected by reporter gene. Activation of nuclear factor-kB (NF-KB) was evaluated by electrophoretic mobility shift assay. The role of NF-KB signaling was analyzed using inhibitors of NF-KB and dominant-negative mutants, and Western blot analysis.
\end{abstract}

Results: C. crepidioides extract delayed tumor growth in S-180-bearing mice. However, it did not inhibit S-180 cell growth in vitro. Supernatant of cultured C. crepidioides-stimulated RAW264.7 macrophages was cytotoxic to S-180 cells. This cytotoxicity was associated with nitric oxide (NO) production. NF-kB signaling pathway was crucial for the transcriptional activation of iNOS gene. Isochlorogenic acid, a component of C. crepidioides, induced NF-KB activation and iNOS expression.

Conclusions: The results highlight the oncolytic and immunopotentiation properties of $C$. crepidioides mediated through NF-KB-induced release of NO from macrophages.

\section{Background}

Plants contain several classes of phytochemicals that have antioxidative, antimutagenic and anticarcinogenic effects. The edible plant, Crassocephalum crepidioides S. MOORE (Japanese name; Benibanaborogiku), is wildly distributed in the Okinawa Islands and used in folk medicine for the treatment of acute hepatitis, fever and edema. Compounds with antimalarial activity and strong antimutagenicity had been isolated previously from $C$. crepidioides [1,2]. Other preparations from $C$. crepidioides have been described to have antioxidant and hepatoprotective properties [3]. However,

\footnotetext{
* Correspondence: naokimori50@gmail.com

${ }^{\dagger}$ Equal contributors

'Department of Microbiology and Oncology, Graduate School of Medicine, University of the Ryukyus, 207 Uehara, Nishihara, Okinawa 903-0215, Japan Full list of author information is available at the end of the article
}

the anticancer activity of C. crepidioides has not been investigated.

This is the first study that examines the antitumor effects of $C$. crepidioides extract. Although this extract is effective in inhibiting the in vivo growth of implanted Sarcoma-180 (S-180) cells, it did not inhibit the growth of the same cells in vitro. Activation of macrophages by agents such as bacterial lipopolysaccharide (LPS) stimulates their growth inhibitory effects against a wide variety of tumor cells [4]. In the present study, we report that $C$. crepidioides extract can induce the production of nitric oxide (NO), a major mediator of the tumoricidal activity of murine macrophages. In addition, serum nitrite and nitrate levels were significantly elevated in mice administered C. crepidioides extract compared with levels in the control group. Specifically, we characterized the mechanisms of the actions of $C$. crepidioides extract

\section{Biomed Central}


on inducible NO synthase (iNOS) promoter in murine macrophages. The antitumor efficacy of the extract was based on immunopotentiation, mediated, at least in part, by isochlorogenic acid.

\section{Methods \\ Reagents}

Fresh C. crepidioides was harvested in Subtropical Field Science Center of the University of the Ryukyus, Okinawa, Japan, and air-dried. Dried C. crepidioides (50 g) was extracted twice with $500 \mathrm{ml}$ of boiling water for $30 \mathrm{~min}$ and the supernatant was decanted. After filtration, the combined supernatants were evaporated in vacuum and finally lyophilized to the powder. The extract obtained was used as an original extract, and dissolved with pure water when necessary. Isochlorogenic acid was purified using the procedure described previously with some modifications [3]. The extract dissolved in pure water was applied to a HP-20 (Mitsubishi Chemical, Tokyo, Japan) column eluting water and increasing amount of methanol $(\mathrm{MeOH})$ to yield $70 \% \mathrm{MeOH}$ fraction. After passing the fraction through C18 Sep-Pak cartridge (Waters, Millford, MA, USA), the final purification of the fraction was carried out by a Toyopearl HW-40 C (Tosho, Tokyo, Japan) column with 50\% $\mathrm{MeOH}$ as an eluent. The $50 \% \mathrm{MeOH}$ fraction contained $94 \%$ of isochlorogenic acid by absorption at $320 \mathrm{~nm}$, following separation by reversed phase HPLC on C18 column (Nomura Chemical, Seto, Japan). C. crepidioides was dissolved in Dulbecco's modified Eagle's medium to a final concentration of $20 \mathrm{mg} / \mathrm{ml}$.

Antibodies to nuclear factor- $\mathrm{kB}(\mathrm{NF}-\mathrm{kB})$ subunits $\mathrm{p} 65$, p50, c-Rel and p52 were purchased from Santa Cruz Biotechnology (Santa Cruz, CA, USA). Antibody to actin was purchased from NeoMarkers (Fremont, CA, USA).

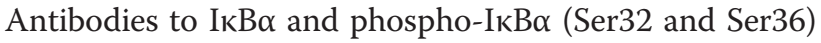
were obtained from Cell Signaling Technology (Beverly, MA, USA). N-acetyl-L-leucyl-L-leucyl-L-norleucinal (LLnL) and Bay 11-7082 were purchased from SigmaAldrich (St Louis, MO, USA) and Calbiochem (La Jolla, CA, USA), respectively.

\section{In vivo therapeutic effect of $C$. Crepidioides}

Four-week-old female BALB/c strain athymic nu/nu mice were obtained from Ryukyu Biotec Co. (Urasoe, Japan). They were engrafted with $2 \times 10^{5} \mathrm{~S}-180$ cells by subcutaneous injection in the back region. Treatment was initiated on the day of cell inoculation. C. crepidioides was dissolved in distilled water at a concentration of $333 \mathrm{mg} / \mathrm{ml}$, and $5 \mathrm{~g} / \mathrm{kg}$ body weight of C. crepidioides was administered by oral gavage every day for 29 days. Tumor size was monitored once a week. All mice were sacrificed on day 28 and the tumors dissected out immediately. Tumors were fixed for paraffin embedding and tissue sectioning, and evaluated histologically using hematoxylin and eosin $(\mathrm{H} \& \mathrm{E})$. This experiment was performed according to the guidelines for Animal Experimentation of the University of the Ryukyus and approved by the Animal Care and Use Committee of the same University.

\section{Cells}

The mouse sarcoma cell line S-180 and macrophage cell line RAW264.7 were cultured in Eagle's Minimum Essential Medium and Dulbecco's modified Eagle's medium supplemented with $10 \%$ heat-inactivated fetal bovine serum, respectively.

\section{Assays for cell growth}

S-180 and RAW264.7 cells were seeded on 96-well plates and cultured for 24 h. C. crepidioides was added at various concentrations and incubated for 24,48 and $72 \mathrm{~h}$. In addition, the culture media were removed and replaced by supernatants from C. crepidioides-stimulated RAW264.7 cells. The growth of cells was evaluated by measuring the mitochondrial-dependent conversion of the water-soluble tetrazolium (WST)-8 (Nacalai Tesque, Kyoto, Japan) to a colored formazan product [5]. After 24, 48 and $72 \mathrm{~h}$ of culture, WST-8 $(5 \mu \mathrm{l})$ was added to each well containing cultured cells in the last $4 \mathrm{~h}$ of incubation. Absorbance at $450 \mathrm{~nm}$ was measured using an automated microplate reader. The cell growth in untreated control cultures was considered $100 \%$, and the growth of each treated group was compared relative to this value.

\section{Measurement of NO}

Nitrite $\left(\mathrm{NO}_{2}^{-}\right)$, the stable end product of $\mathrm{NO}$ was measured in the supernatants by the colorimetric assay. Briefly, the medium was removed from individual wells and treated with Griess reagent (1\% sulphanilamide and $0.1 \%$ naphtylethylene diamine dihydrochloride in $2 \%$ $\mathrm{H}_{3} \mathrm{PO}_{4}$ ) for $10 \mathrm{~min}$ at room temperature. The optical density of the samples was obtained using an automated microplate reader at $550 \mathrm{~nm}$. A standard curve using a standard solution of $\mathrm{NaNO}_{2}$ in culture medium was employed to calculate the nitrite concentration. The levels of nitrite $\left(\mathrm{NO}_{2}^{-}\right)$and nitrate $\left(\mathrm{NO}_{3}^{-}\right)$anions derived from $\mathrm{NO}$ in murine sera were measured by an ENO-20 NO analyzer (EiCOM, Kyoto, Japan).

\section{Western blot analysis}

Cells were lysed and equal amounts of protein $(20 \mu \mathrm{g})$ were subjected to electrophoresis on sodium dodecyl sulphate-polyacrylamide gels followed by transfer onto a polyvinylidene difluoride membrane and probing with the specific antibodies. The bands were visualized with an enhanced chemiluminescence kit (Amersham Biosciences, Piscataway, NJ, USA). The reported results were 
obtained from at least two independent experiments with a similar pattern.

Reverse transcriptase-polymerase chain reaction (RT-PCR) Total cellular RNA was extracted with TRIzol (Invitrogen, Carlsbad, CA, USA). First-strand cDNA was synthesized from $1 \mu \mathrm{g}$ total cellular RNA using an RNA-PCR kit (Takara Bio Inc., Otsu, Japan) with random primers. The primers used were 5'-TCATTGTACTCTGAGGGCTGA CACA-3' (forward) and 5'-GCCTTCAACACCAAG GTTGTCTGCA-3' (reverse) for murine iNOS, and 5'-GTGGGGCGCCCCAGGCACCA-3' (forward) and 5'-CTCCTTAATGTCACGCACGATTTC-3' (reverse) or $\beta$-actin. The length of RT-PCR was 25 cycles for iNOS and 28 cycles for $\beta$-actin. The PCR products were fractionated on $2 \%$ agarose gels and visualized by ethidium bromide staining.

\section{Transfection and luciferase assay}

The I $\mathrm{KB} \alpha \Delta \mathrm{N}$ - and I $\mathrm{K} \mathrm{B} \beta \Delta \mathrm{N}$-dominant-negative mutants are $I \kappa B \alpha$ and $I \kappa B \beta$ deletion mutants lacking the $\mathrm{N}$ terminal 36 and 23 amino acids, respectively [6, 7]. The dominant-negative mutants of IкB kinase (IKK) $\alpha$, IKK $\alpha$ (K44M), IKK $\beta$, IKK $\beta$ (K44A), IKK $\gamma$, IKK $\gamma$ (1-305) and NF-кB-inducing kinase (NIK), NIK (KK429/430AA) have been described previously [8, 9]. pGL3 iNOS plasmid was generated by inserting the murine iNOS promoter region $(-1588$ to +161 bp surrounding the transcription start site) into the pGL3-basic vector (Promega, Madison, WI, USA) [10]. Three internal deletion mutants, pGL3 iNOS $\kappa$ B2-, pGL3 iNOS $\kappa$ B1- and pGL3 iNOS $\kappa \mathrm{B} 1 / \kappa \mathrm{B} 2-$, were constructed by deletion of two NF- $\mathrm{B}$ sites defined as the $\kappa \mathrm{B} 1(-85$ to -76$)$ and $\kappa \mathrm{B} 2(-971$ to -962). For reporter assays, an NF- $k B$ site-dependent luciferase vector, $\mathrm{kB}$-LUC [11] was also used. RAW264.7 cells were plated and transfected with the appropriate reporter and effector plasmids using Lipofectamine reagent (Invitrogen). After 18-20 h, C. crepidioides was added and incubated for $6 \mathrm{~h}$. The cells were lysed in reporter lysis buffer (Promega). Lysates were assayed for reporter gene activity with the dual-luciferase assay system (Promega). Luciferase activities were normalized relative to the Renilla luciferase activity from phRL-TK.

\section{Electrophoretic mobility shift assay (EMSA)}

Nuclear extracts were obtained as described by Antalis and Godbolt [12] with modifications, and EMSA was performed as described previously [13]. The probes used were prepared by annealing the sense and antisense synthetic oligonucleotides; a $\kappa \mathrm{B} 1$ site from the murine iNOS gene (5'-tcgaCCAACTGGGGACTCTCCCTTTGGGAA3'), a кB2 site from the murine iNOS gene (5'-tcgaTGC TAGGGGGATTTTCCCTCTCTCTG-3') and an AP-1 element of the interleukin (IL)-8 gene (5'-gatcGTGAT
GACTCAGGTT-3'). The above underlined sequences represent the NF-kB or AP-1 binding site. The reported results were obtained from at least two independent experiments with a similar pattern.

\section{Statistical analysis}

Data are expressed as mean \pm SD. Differences between groups were assessed for statistical significance by the Mann-Whitney's $U$-test. A P value $<0.05$ denoted the presence of a statistically significant difference.

\section{Results}

\section{Effects of C. Crepidioides in nude mice inoculated with S-180 cells}

To explore the effect of $C$. crepidioides on tumor growth in nude mice transplanted with murine S-180, we treated tumor-bearing mice with $5 \mathrm{~g} / \mathrm{kg}$ of $C$. crepidioides extract. The mean tumor volume was significantly lower than that of control mice after 14-day treatment $(P=0.0433$, Figure 1A). However, the difference in tumor volume after 21- and 27-days treatment, compared with control, was less conspicuous. There was no significant difference in body weight gain from day 0 to day 28 between the control and C. crepidioides-treated groups (data not shown), and mice treated with $C$. crepidioides appeared generally healthy during the same period. On the other hand, treatment of S-180 cells with C. crepidioides for 29 days produced strong H\&E staining for apoptosis (Figure 1B). These results suggest that $C$. crepidioides has antitumor in vivo effect.

\section{Supernatant from C. crepidioides-stimulated RAW264.7 cells but not $C$. crepidioides alone causes cell growth inhibition of S-180 cells}

To study the mechanism of the antitumor effect of $C$. crepidioides, we determined the effects of $C$. crepidioides on cell growth of S-180 cells in vitro. Cell growth was assessed by the WST- 8 assay. Incubation with $C$. crepidioides alone at concentrations up to $500 \mu \mathrm{g} / \mathrm{ml}$ for $72 \mathrm{~h}$ did not affect cell growth (Figure 1C). Activation of macrophages by agents such as bacterial LPS stimulates their growth inhibitory effects on a wide variety of tumor cells [4]. Based on this property, we investigated the effects of macrophages on S-180 cells. RAW264.7 cells were incubated with various concentrations of $C$. crepidioides. C. crepidioides did not have any growth inhibitory activity on RAW264.7 cells at concentrations up to $500 \mu \mathrm{g} / \mathrm{ml}$ for $24 \mathrm{~h}$, but a mild inhibitory effect was noted at $500 \mu \mathrm{g} / \mathrm{ml}$ and incubation for 48 and $72 \mathrm{~h}$ (Figure 1D).

S-180 cells were also cultured with supernatants from RAW264.7 cells that had been stimulated by various concentrations of $C$. crepidioides for $72 \mathrm{~h}$. The supernatants suppressed cell growth of S-180 cells in a C. crepidioides dose-dependent manner (Figure 2A), while C. crepidioides- 


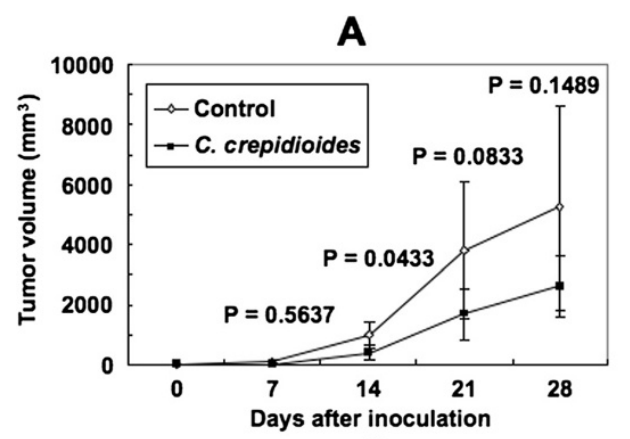

C

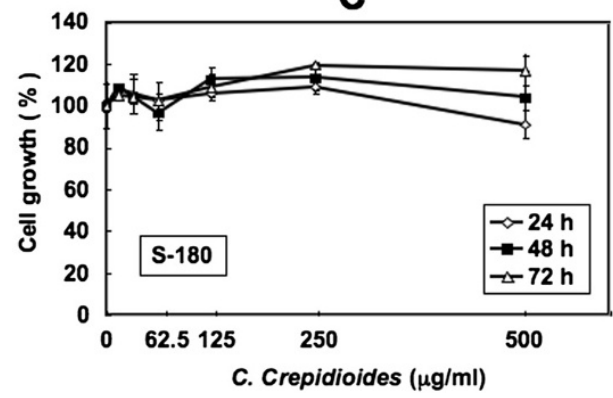

B

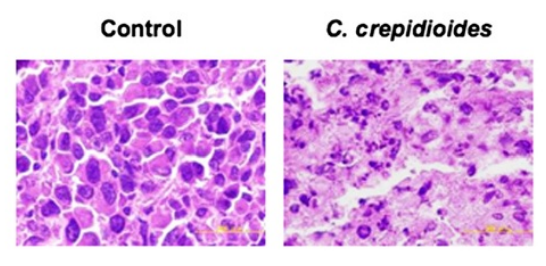

D

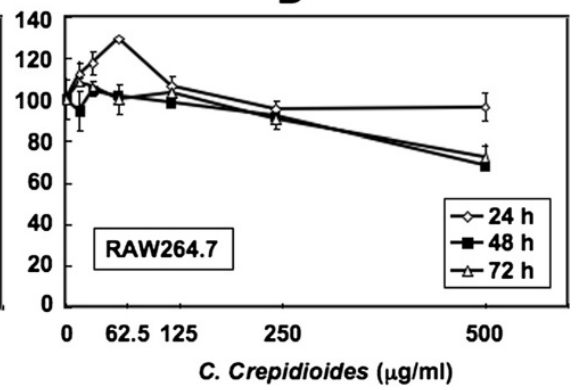

Figure 1 In vivo and in vitro antitumor activities of C. crepidioides on S-180 cells. (A) Inhibition of growth of S-180 cells in nude mice. Growth of the tumors after subcutaneous inoculation of S-180 cells. Note the growth-suppressive effect of C. crepidioides. Data are mean \pm SD of four mice in each group. The $\mathrm{P}$ values are the results of statistical analysis of the C. crepidioides and control data. (B) H\&E-stained tissues demonstrating the pathological changes induced by treatment with C. crepidioides. Magnification, $\times 1000$. (C) C. crepidioides does not have any antitumor activity on S-180 cells by itself. S-180 cells were cultured with the indicated concentrations of C. crepidioides extract for 24,48 or 72 h, and cell growth was determined in triplicate cultures by WST-8 assay. (D) Cytotoxic effect of C. crepidioides on RAW264.7 cells. The cell growth was determined in triplicate cultures by WST-8 assay. Cell growth in untreated control cultures was considered 100\%. Data are mean \pm SD of triplicate cultures expressed as percentage of the control.

containing control medium had no growth inhibitory activity on S-180 cells, similar to the data shown in Figure $1 \mathrm{C}$ (Figure 2B).

\section{Crepidioides induces NO production and expression of iNOS mRNA}

Previous studies demonstrated the crucial role of NO in the tumoricidal activity of murine macrophages [14-16]. The addition of exogenous NO donor, NOR3, to the culture medium of S-180 cells inhibited cell growth (data not shown). Therefore, we examined the effects of $C$. crepidioides on NO production by RAW264.7 cells in vitro. NO production by stimulated RAW264.7 cells was assessed by measuring nitrite in the culture medium. $C$. crepidioides stimulated the production of nitrite from RAW264.7 cells in time- and dose-dependent manners (Figure $2 \mathrm{C}$ and $\mathrm{D})$. In in vivo experiments, mice orally administered $C$. crepidioides had significantly high serum nitrite and nitrate levels compared with the control (Figure 3).

What is the mechanism of C. crepidioides-stimulated NO production? NO is synthesized by NOS-catalyzed conversion of L-arginine to L-citrulline. Whereas the activity of neuronal and endothelial NOS is mainly regulated post-translationally by cytoplasmic calcium levels or by phosphorylation by various protein kinases, iNOS is primarily regulated at the transcriptional level [17]. Next, we determined whether $C$. crepidioides-induced NO production from RAW264.7 cells was catalyzed by iNOS. The addition of $500 \mu \mathrm{g} / \mathrm{ml} \mathrm{C}$. crepidioides to RAW264.7 cells resulted in the expression of iNOS mRNA from $1 \mathrm{~h}$ after treatment (Figure 4A). In another setting, incubation with C. crepidioides for $3 \mathrm{~h}$ at $15.6 \mu \mathrm{g} / \mathrm{ml}$ induced iNOS mRNA expression in RAW264.7 cells (Figure 4B). The main antioxidant isolated from $C$. crepidioides is isochlorogenic acid [3]. Isochlorogenic acid stimulated iNOS expression in a manner similar to that by $C$. crepidioides (Figure $4 \mathrm{C}$ and D). These results suggest that the $C$. crepidioides-induced increase in NO production by RAW264.7 cells is mediated by the induction of iNOS expression, and that isochlorogenic acid seems to contribute to at least part to this augmented production of NO.

NF-KB sites are necessary for C. Crepidioides inducibility of iNOS promoter

To assess the effect of $C$. crepidioides on iNOS promoter activity, RAW264.7 cells were transfected with a murine iNOS-luciferase promoter/reporter construct and then 
A

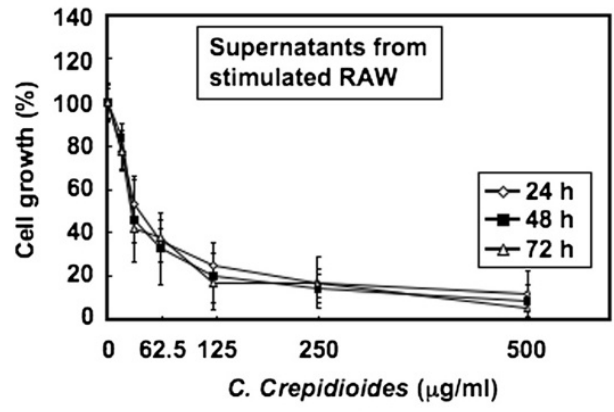

C

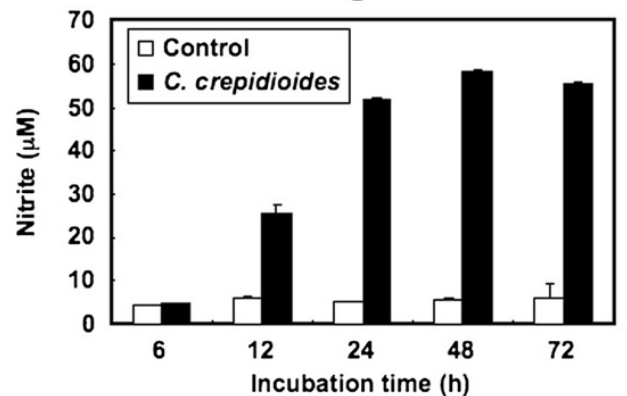

B

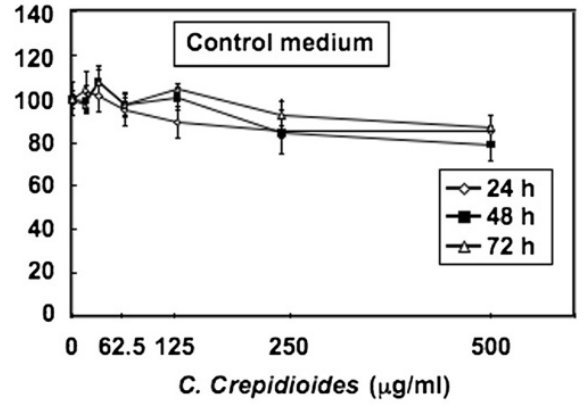

D

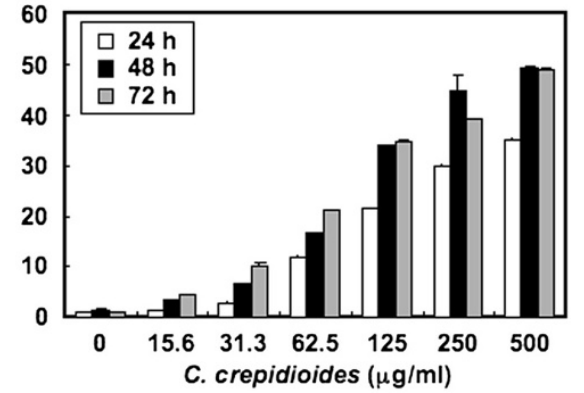

Figure 2 Antitumor effect of supernatants from C. crepidioides-stimulated RAW264.7 cells on S-180 cells and effects of $C$. crepidioides on NO production in RAW264.7 cells. (A, B) Antitumor effects of supernatants from C. crepidioides-stimulated RAW264.7 cells against S-180 cells, measured by WST-8 assay. RAW264.7 cells were cultured with various concentrations of C. crepidioides extract for $72 \mathrm{~h}$. The control samples did not include RAW264.7 cells. At the end of each incubation period, the supernatant was collected. S-180 cells were precultured for $24 \mathrm{~h}$. Thereafter, the culture media were removed and replaced with supernatants from C. crepidioides-stimulated RAW264.7 cells (A) or by the control medium (B). S-180 cells were incubated for another 24,48 or $72 \mathrm{~h}$, and cell growth was determined in triplicate cultures by WST-8 assay. Cell growth in control cultures (supernatants from unstimulated RAW264.7 cells (A) or control medium in the absence of C. crepidioides (B)) was considered 100\%. Data are mean \pm SD values expressed as percentage of the control. (C, D) Effects of C. crepidioides on NO production in RAW264.7 cells. RAW264.7 cells were incubated with or without C. crepidioides $(500 \mu \mathrm{g} / \mathrm{ml})$ (C) or with various concentrations of C. crepidioides (D) for the indicated time periods. NO production was determined by measuring the accumulation of nitrite in the culture medium. Data are mean \pm SD of triplicate cultures.

incubated with various concentrations of C. crepidioides. The cells were lysed, and luciferase activity was measured. C. crepidioides increased the expression of luciferase from the iNOS promoter in a dose-dependent manner (Figure 5A). The expression of the iNOS gene in macrophages is regulated mainly at the transcriptional level, particularly by NF-kB [18-21]. The murine iNOS promoter contains two putative NF- $\mathrm{kB}$ binding sites, one upstream (GGGATTTTCC, -971 to $-962 \mathrm{bp}$, designated NF-kB2) and one downstream (GGGAC TCTCC, -85 to $-76 \mathrm{bp}$, designated NF-кB1). To test the relative contribution of the NF- $\mathrm{KB}$ binding sites to the $C$. crepidioides-mediated activation of iNOS, we introduced a deletion into each or both sites. A single deletion of the $\mathrm{\kappa B} 2$ site markedly inhibited $C$. crepidioides-mediated promoter activation, whereas a single deletion of the $\mathrm{kB1}$ site resulted in moderate activation. On the other hand, double deletion completely abolished the C. crepidioides-mediated promoter activation (Figure 5B).

\section{Crepidioides induces binding of NF-KB family proteins} to two NF-KB sites

We next characterized the nuclear proteins in $C$. crepidioides-treated RAW264.7 cells that bind to sequences from the iNOS promoter in an NF-kBdependent manner. EMSA was performed using two probes; miNOS $\kappa \mathrm{B} 1$ and $\kappa \mathrm{B} 2$, oligonucleotides consisting

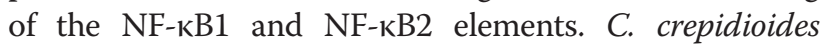
induced a time-dependent appearance of nuclear proteins that bound to both probes in RAW264.7 cells (Figure 6A). In both probes, the addition of excess unlabeled $\mathrm{\kappa B} 1$ and $\mathrm{\kappa B} 2$ oligonucleotides to the binding reaction completely abolished the formation of inducible DNA-protein complexes (Figure 6B, lanes 2 and 9). In contrast, the formation of these DNAprotein complexes was not blocked by the addition of excess of unrelated oligonucleotide AP-1 (Figure 6B, lanes 3 and 10). To identify the NF-kB family members that bind to the NF- $\mathrm{kB}$ motifs of the murine iNOS gene promoter, the binding reactions 

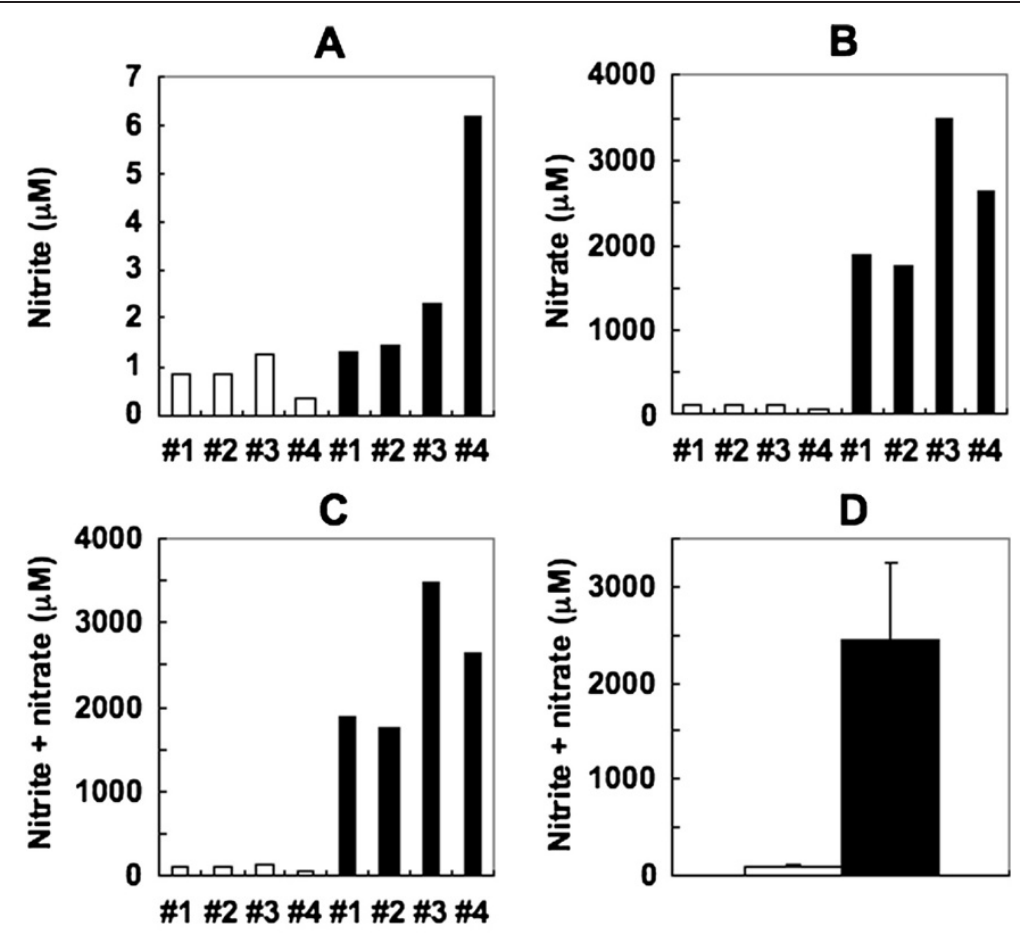

\section{$\square$ Control \\ - c. crepidioides}

Figure 3 Effect of oral administration of $C$. crepidioides $\left(5 \mathrm{~g} / \mathrm{kg}\right.$ ) on serum levels of nitrite $\left(\mathrm{NO}_{2}^{-}\right)$and nitrate $\left(\mathrm{NO}_{3}^{-}\right)$. (A-C) Serum levels of nitrite $(\mathbf{A})$, nitrate (B) and nitrite plus nitrate (C, D) in C. crepidioides-treated and untreated mice at day 28. (D) Data are mean \pm SD of four mice in each group.

were preincubated with antibodies specific to p50, p65, c-Rel and p52. The anti-p50 and anti-p65 antibodies induced the supershifted bands and reduced the intensity of complexes $\kappa \mathrm{B} 1$ and $\kappa \mathrm{B} 2$ (Figure 6B, lanes 4, 5, 11 and
12). The c-Rel antibody also supershifted complexes $k B 1$ and $\mathrm{kB2}$ (Figure 6B, lanes 6 and 13). These results indicate that the complexes $\kappa B 1$ and $\kappa B 2$ correspond to $p 50 / p 65 /$ c-Rel.

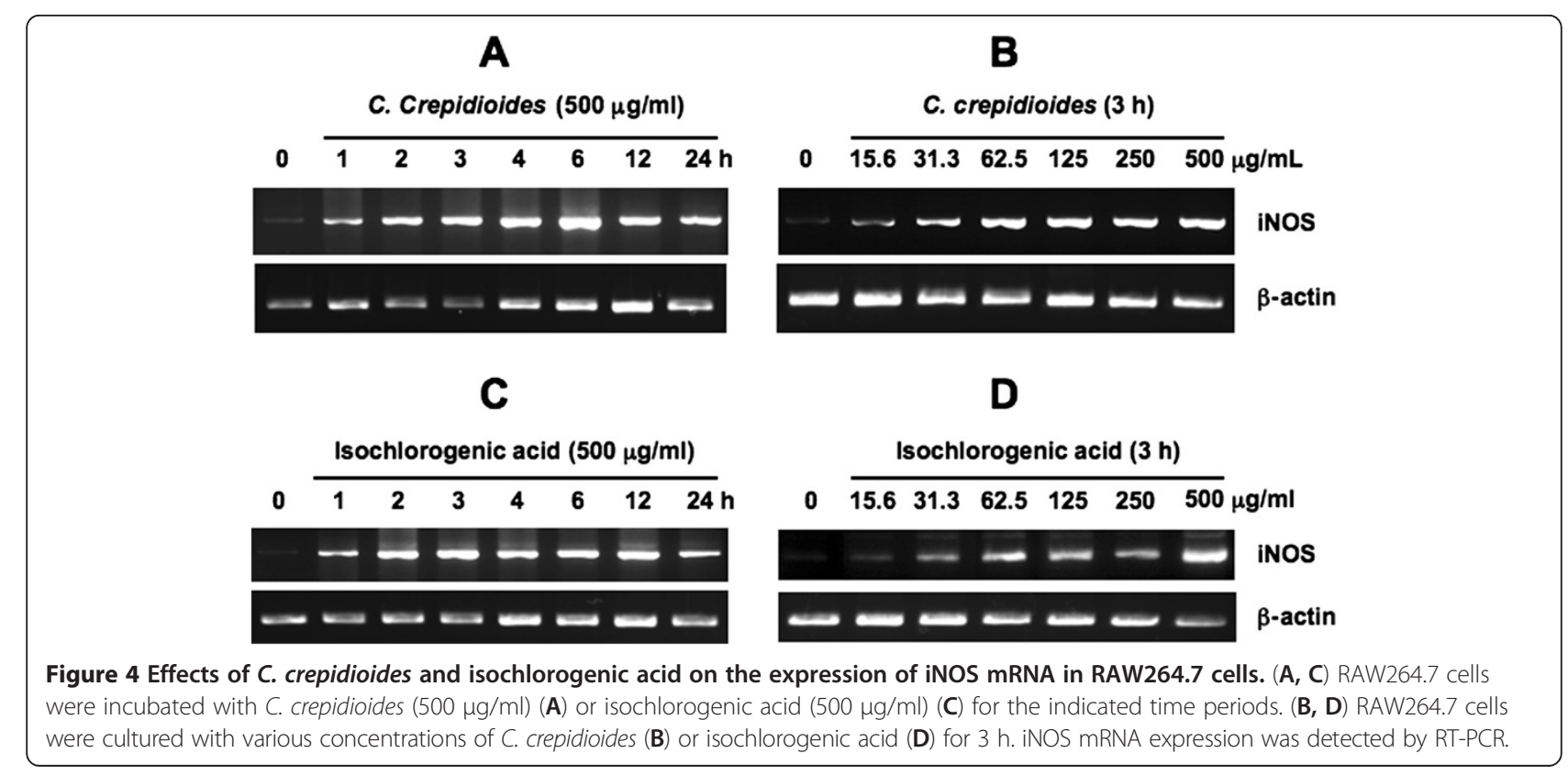


A

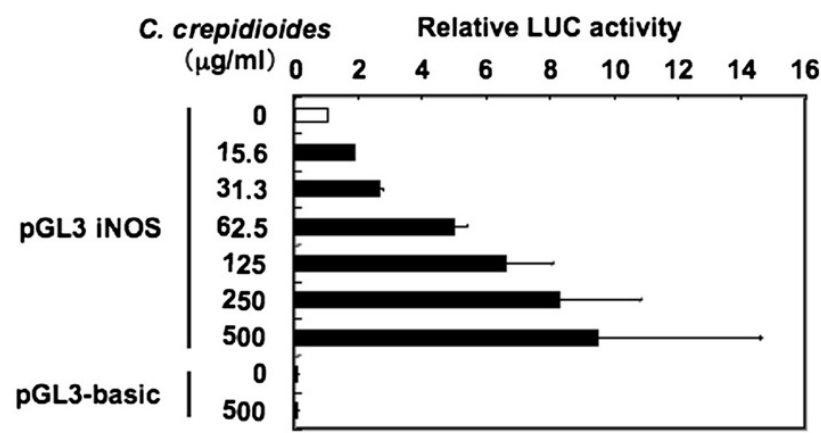

B

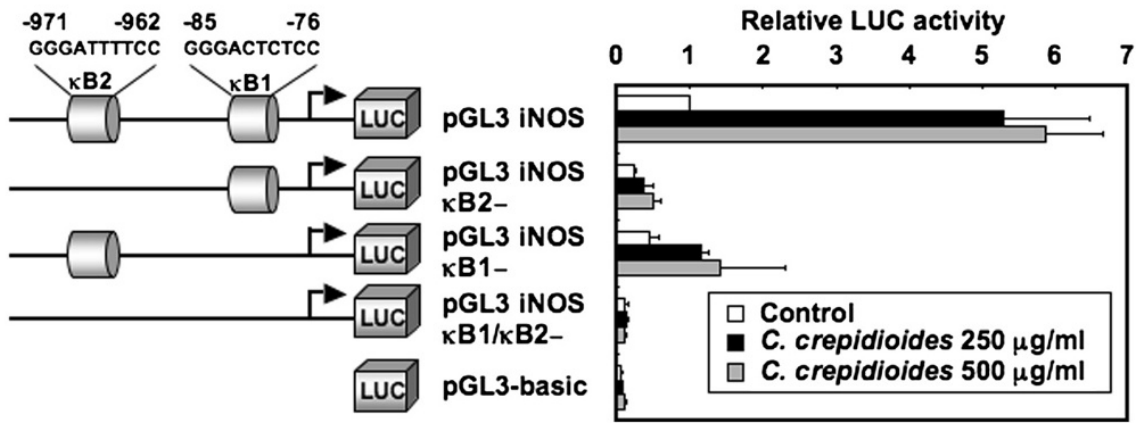

Figure 5 NF-KB sites in murine iNOS promoter are essential for C. crepidioides responsiveness. (A) RAW264.7 cells were transfected with a murine iNOS promoter construct (pGL3 iNOS) or pGL3-basic, and then treated with the indicated concentrations of C. crepidioides for $6 \mathrm{~h}$ and lysed for luciferase activity analysis. All values were calculated as change ( $n$-fold) in induction values relative to the basal level measured in untreated cells. (B) RAW264.7 cells were transfected with the indicated luciferase reporter plasmids. After transfection, the cells were left untreated or treated with C. crepidioides $(250$ and $500 \mu \mathrm{g} / \mathrm{ml}$ ) for $6 \mathrm{~h}$, and luciferase activity was measured. The activities are expressed relative to that of cells transfected with PGL3 iNOS without further treatment, which was defined as 1. Luciferase activity was normalized relative to the Renilla luciferase activity from phRL-TK. LUC, luciferase. Data are mean \pm SD of three independent experiments.

NF-KB signal is essential for C. Crepidioides-induced iNOS expression

Does C. crepidioides-mediated upregulation of iNOS gene expression involve signal transduction components in NF- $\kappa B$ activation? Activation of NF- $\kappa B$ requires the phosphorylation of two conserved serine residues of NF-

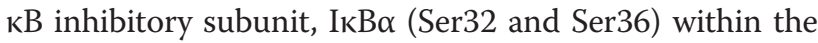
N-terminal domain [22]. Phosphorylation leads to the ubiquitination and $26 \mathrm{~S}$ proteasome-mediated degradation of $\mathrm{I} \kappa \mathrm{B} \alpha$, thereby releasing NF- $\mathrm{B}$ from the complex and its translocation to the nucleus and activation of various genes [22]. Next, we determined the role of I $\mathrm{B} \mathrm{B} \alpha$ phosphorylation and degradation in C. crepidioidesinduced NF- $\mathrm{kB}$ translocation and activation by Western blot analysis using antibodies against phosphorylated and total IkB $\alpha$. Treatment of RAW264.7 cells with $C$. crepidioides resulted in phosphorylation and degradation of IkB $\alpha$ within 30 min (Figure $6 \mathrm{C}$ ).

Next, RAW264.7 cells were transfected with the luciferase reporter plasmid regulated by NF- $\mathrm{kB}$ elements (кB-LUC; [11]) and then incubated with C. crepidioides (Figure 6D). The results showed that $C$. crepidioides induced NF- $\mathrm{KB}$ activation. To further confirm the involvement of $\mathrm{I}_{\kappa} \mathrm{B} \alpha$ phosphorylation and degradation, we transfected the cells with transdominant mutant of I $\mathrm{KB} \alpha$ in which two critical serine residues required for inducer-mediated phosphorylation were deleted [6]. Overexpression of mutant $\mathrm{I} \kappa \mathrm{B} \alpha$ inhibited the $C$. crepidioides-induced iNOS promoter activation (Figure 6D), suggesting the involvement of $\mathrm{I} \kappa \mathrm{B} \alpha$ phosphorylation and degradation in C. crepidioides-induced iNOS expression.

$\mathrm{I} \kappa \mathrm{B} \beta$ also contains an $\mathrm{N}$-terminal regulatory region required for stimulus-induced degradation, a key step in NF- $\kappa B$ activation [22]. Overexpression of mutant I $\mathrm{B} \beta$ in which two critical serine residues required for inducermediated phosphorylation were deleted [7], also inhibited the $C$. crepidioides-induced iNOS promoter activation (Figure 6D). These results suggest the involvement of I $\mathrm{B} \beta \beta$ phosphorylation and degradation in C. crepidioidesinduced iNOS expression.

The IKK complex consists of two catalytic subunits $\mathrm{IKK} \alpha$ and $\mathrm{IKK} \beta$, and the regulatory subunit IKK $\gamma$ [22]. In the NF- $\kappa B$ activation pathway, IKK complex can induce serine phosphorylation of $\operatorname{I\kappa B} \alpha$ and $\operatorname{I\kappa B} \beta$ [22]. 


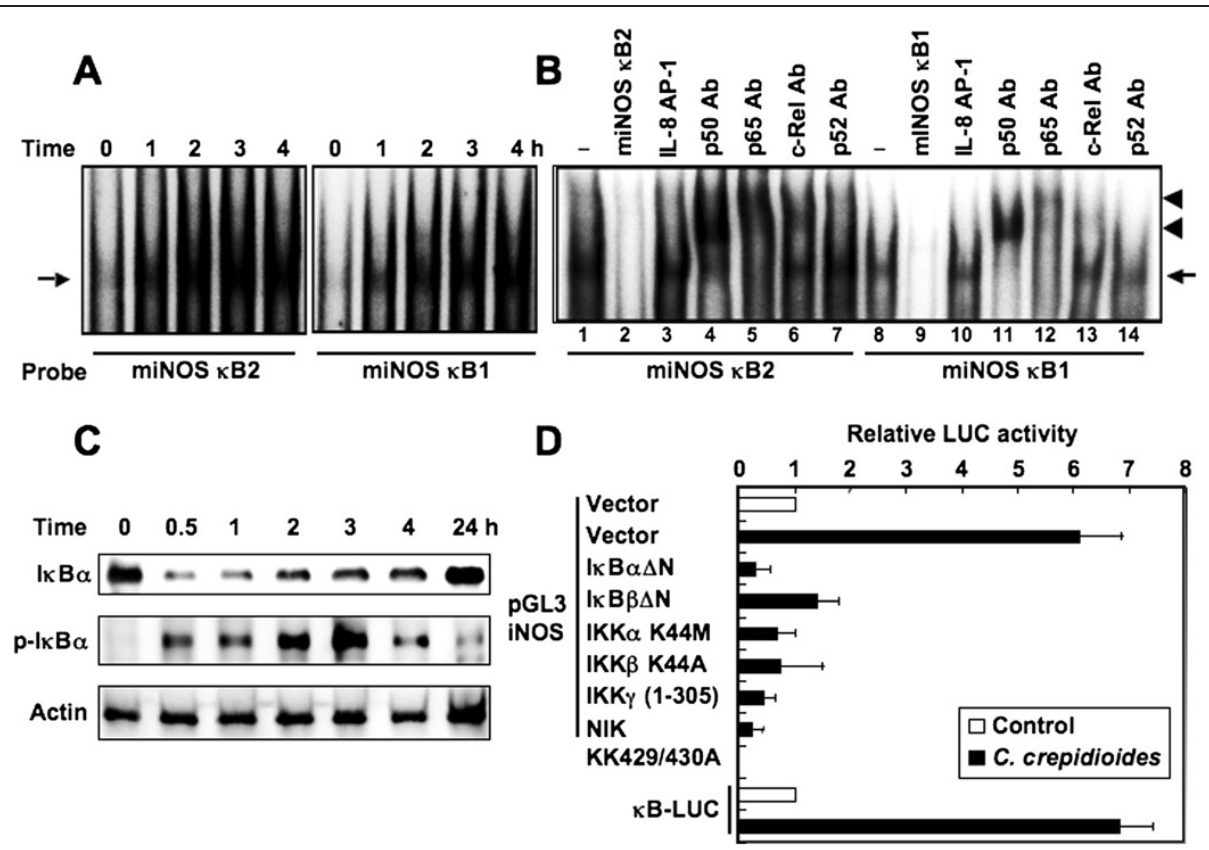

Figure 6 Effects of $C$. crepidioides on signal pathway through NF-kB activation. (A) NF-kB1- and NF-kB2-dependent binding of nuclear proteins in RAW264.7 cells. The cells were treated with C. crepidioides $(500 \mu \mathrm{g} / \mathrm{ml})$ for the indicated time periods before preparing nuclear extracts for analysis by EMSA with probe miNOS KB1 or KB2. (B) Sequence specificity of NF-kB binding activity and characterization of proteins that bound to the NF-kB binding sites. Competition assays were performed with nuclear extracts from cells treated with C. crepidioides (500 $\mu \mathrm{g} / \mathrm{ml})$ for $2 \mathrm{~h}$. Excess amounts of competitor (100-fold) were added (lanes 2, 3, 9 and 10). Supershift assay in the same nuclear extracts was also performed. Antibodies (Ab) were added (lanes 4-7 and 11-14). Arrows: specific complexes, arrowheads: supershifted DNA binding complexes. (C) C. crepidioides induces phosphorylation and degradation of IkBa. Cells were treated with C. crepidioides $(500 \mu \mathrm{g} / \mathrm{ml})$ for the indicated time periods and lysates were subjected to immunoblotting. (D) Overexpression of dominant-negative mutants inhibits C. crepidioides-induced activation of the iNOS promoter. Cells were transfected with PGL3 iNOS or KB-LUC and the mutant plasmids and then treated with C. crepidioides (500 $\mu \mathrm{g} / \mathrm{ml}$ ) for $6 \mathrm{~h}$. Open bar: luciferase activity of pGL3 iNOS and empty vector or KB-LUC alone without treatment. All values were calculated as the change ( $n$-fold) in induction value relative to the basal level measured in untreated cells. LUC, luciferase. Data are mean \pm SD of three independent experiments.

Previous studies suggested the involvement of serine/ threonine kinase NIK in phosphorylation and activation of the IKK complex [23]. To determine the roles of NIK, IKK $\alpha, I K K \beta$ and IKK $\gamma$ in C. crepidioides-induced iNOS expression in RAW264.7 cells, plasmids encoding dominant-negative mutants of NIK, IKK $\alpha, I K K \beta$ and IKK $\gamma$ were used. As shown in Figure 6D, transfection with dominant-negative mutants of NIK, IKK $\alpha$, IKK $\beta$ and IKK $\gamma$ significantly attenuated $C$. crepidioidesinduced iNOS expression. Taken together, these findings demonstrate that $C$. crepidioides induces iNOS expression via activation of NF- $k B$ mediated through the NIK/ IKK pathway.

\section{Isochlorogenic acid activates NF-KB}

To determine the role of active compounds on $C$. crepidioides-induced iNOS expression, we examined whether isochlorogenic acid activates NF- $\mathrm{kB}$. Treatment of RAW264.7 cells with isochlorogenic acid resulted in phos-

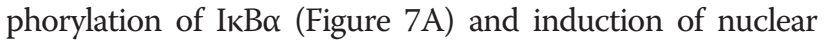
proteins that bound to both miNOS $\kappa B 1$ and $\kappa B 2$ probes (Figure $7 \mathrm{~B}$ ). These results suggest that isochlorogenic acid in C. crepidioides seems to contribute at least in part to the induction of iNOS expression through IкBa phosphorylation and subsequent NF- $\mathrm{kB}$ activation.

\section{Effects of NF-KB inhibitors on C. Crepidioides-induced iNOS expression and NO production}

Because activation of the iNOS promoter by $C$. crepidioides required the activation of NF- $\mathrm{kB}$, we blocked NF$\kappa B$ activation with Bay 11-7082, an inhibitor of ІкB $\alpha$ phosphorylation [24] or LLnL, a proteasome inhibitor [25]. Bay 11-7082 and LLnL reduced C. crepidioidesinduced iNOS promoter activity (Figure $8 \mathrm{~A}$ ). In addition, Bay 11-7082 and LLnL diminished C. crepidioidesinduced iNOS mRNA expression and NO production in RAW264.7 cells (Figure 8B and C).

\section{Discussion}

Alternative therapeutic tools obtained from plants to fight cancer have attracted great interest. This is the first study to report the antitumor effect of $C$. crepidioides extract in S-180 cell-bearing mice. The results demonstrated the effectiveness of $C$. crepidioides in inhibiting 


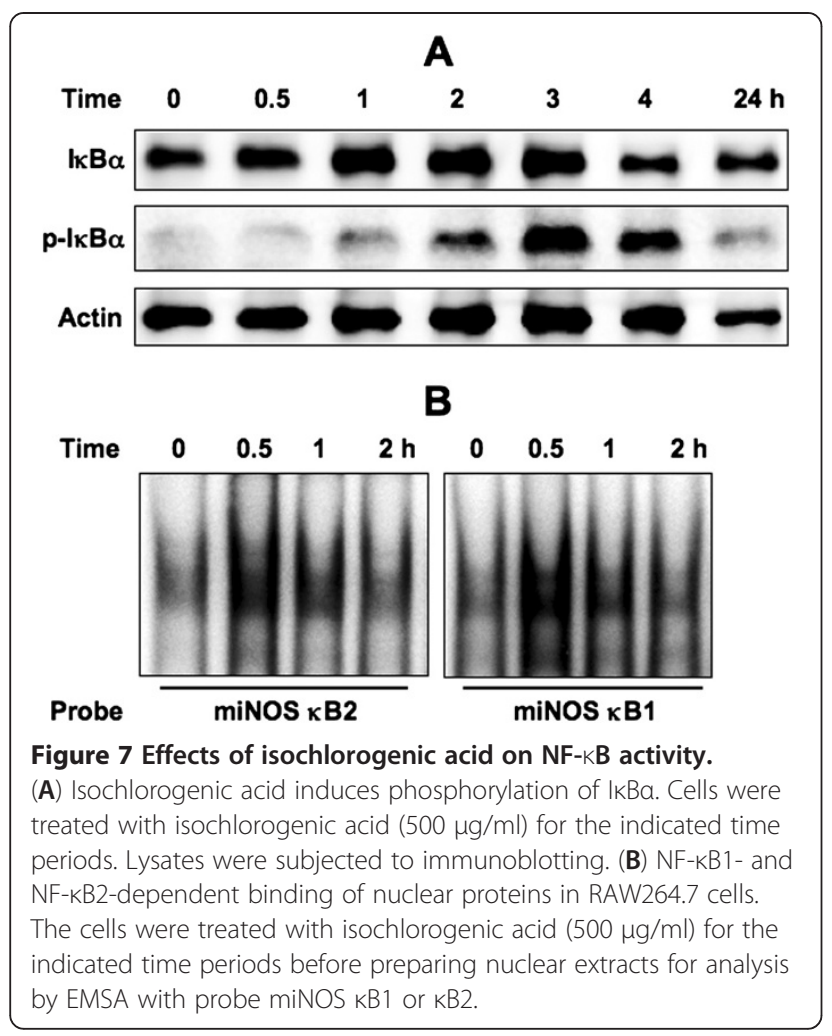

the growth of implanted S-180 cells, although this effect was not mirrored in the in vitro studies. Activated macrophages are important in host defense against tumors, including tumor cytotoxicity. NO appears to be a major mediator of macrophage tumoricidal activity [14-16]. NO secreted by activated macrophages inactivates iron-containing enzymes critical to the viability of tumor cells [26]. The present study was designed to determine whether C. crepidioides extract activated macrophages to the tumoricidal phenotype.

The results demonstrated that $C$. crepidioides extract alone did not inhibit S-180 cell growth in vitro. However, the supernatant from C. crepidioides-treated RAW264.7 cells inhibited S-180 cell growth. This antitumor activity was associated with NO production in activated RAW264.7 cells, and administration of $C$. crepidioides in mice induced a significant increase in serum nitrite and nitrate levels. Thus, NO seems a significant component of the pathway responsible for tumor regression. In this context, it should be emphasized that this experimental approach only allows the study of the effects mediated by soluble mediators. Other interactions involving direct contact between S-180 cells and neighboring macrophages will have additional effects on S-180 cells, modulating the proliferation and apoptosis of S-180 cells.

Another part of the present study investigated the molecular mechanism of C. crepidioides-induced NO production. NO formation is catalyzed by iNOS from Larginine. Macrophage iNOS is not expressed in resting cells and differs from the constitutive neuronal and endothelial NOS [17]. Extensive studies of the transcriptional control of iNOS expression in murine macrophages have stressed the importance of binding of NF-kB [18-21], IRF-1 [27], Stat1 [28] and Oct-1 [29, 30] to their recognition sequences on the iNOS promoter region for activation of iNOS transcription by interferon $\gamma$, LPS, IL-6 and Taxol. We showed here that $C$. crepidioides rapidly activated NF- $k B$. Moreover, we confirmed the essential role of $\mathrm{NF}-\mathrm{kB}$ in C. crepidioides-induced iNOS promoter activity using deletion mutant forms of the two NF- $\mathrm{kB}$ recognition sites in the iNOS promoter, termed NF- $\mathrm{kB} 1$ and NF- $\mathrm{B} 2$. Nuclear protein complexes that bind specifically to NF-kB1 and NF-kB2 after treatment of RAW264.7 cells with $C$. crepidioides contained p50/p65/c-Rel. The components of the NF- $\mathrm{B}$ complexes formed in response to LPS consisted primarily of $\mathrm{p} 50$, with very low levels of p65 and c-Rel subunits [18, 21]. These results support the view that LPS and $C$. crepidioides extract activate NF- $\kappa B$ through the same signaling pathway. Because various phytochemicals have been shown to suppress LPS-induced iNOS expression [31], we examined the effects of C. crepidioides extract on LPS-induced iNOS mRNA expression and NO production. However, C. crepidioides failed to suppress both events induced by LPS (data not shown).

Bay 11-7082 and LLnL are relatively specific inhibitors of NF- $\mathrm{kB}$ activation [24, 25]. Both agents blocked the promoter activity of iNOS, the expression of iNOS mRNA, and the production of nitrite, indicating the likely involvement of $\mathrm{NF}-\mathrm{kB}$ in the induction of not just iNOS-driven reporter constructs but also the iNOS gene itself in C. crepidioides-treated macrophages. We also confirmed the important role of NF- $\mathrm{kB}$ and the upstream target of $C$. crepidioides by showing that overexpression of dominant-negative potent inhibitors of NF- $\mathrm{kB}$ activation (NIK, IKKs and IKBs) inhibited C. crepidioides-induced activation of iNOS promoter.

Compounds with antioxidant activities have been isolated previously from C. crepidioides [3], including isochlorogenic acid and the flavonoids quercetin and kaempferol. However, the latter two have antiinflammatory properties and are known to inhibit LPSinduced iNOS expression and NO production [32, 33]. For this reason, isochlorogenic acid was selected in this study. Results indicated that isochlorogenic acid induces NF- $\kappa B$ activation and subsequent iNOS induction, and thus contributes, at least in part, to the tumoricidal effects of C. crepidioides.

Considered together, our results indicated that C. crepidioides causes regression of murine S-180 tumor and that this effect is mediated by activated macrophages 


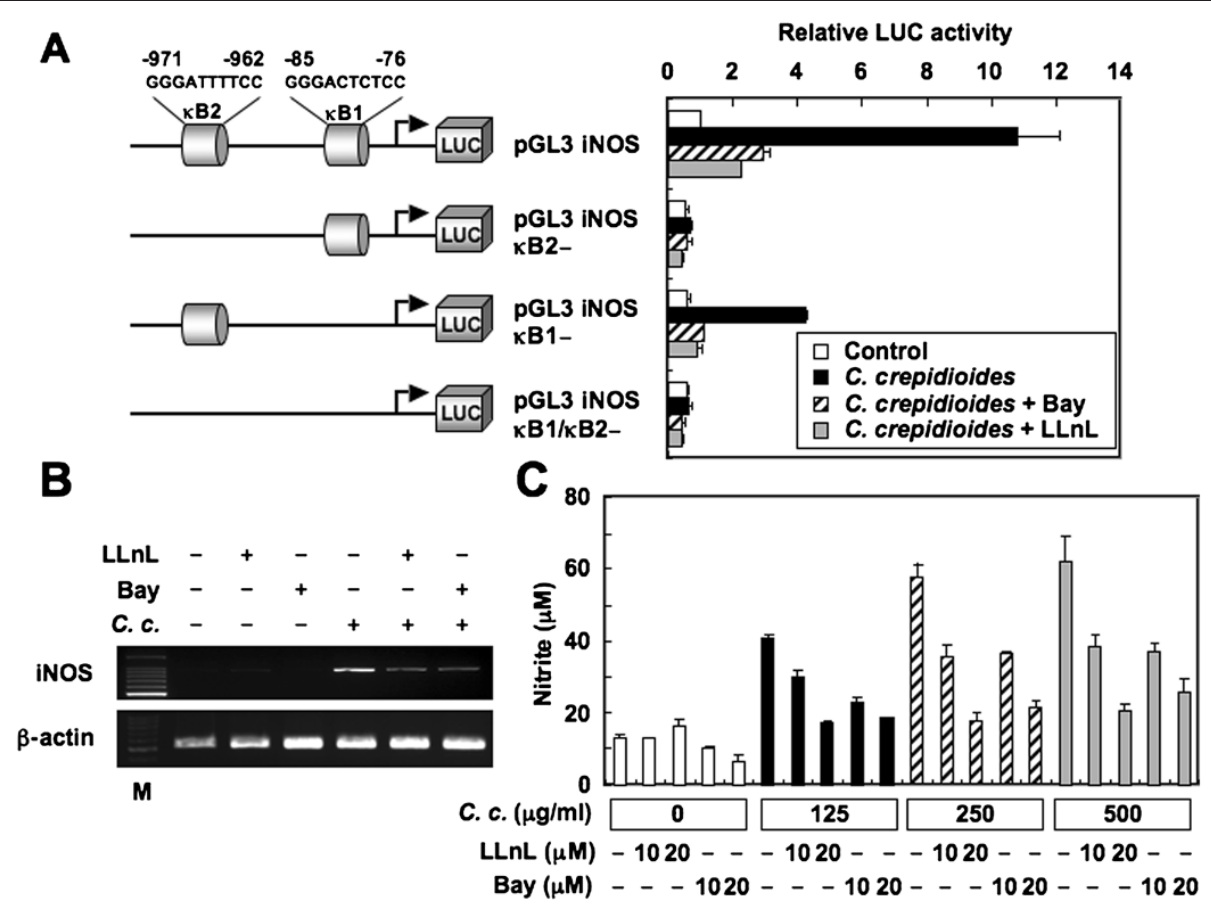

Figure 8 Effects of Bay 11-7082 and LLnL on C. crepidioides-induced iNOS expression and NO production in RAW264.7 cells. (A) iNOS reporter gene analysis. RAW264.7 cells were transfected with the indicated luciferase reporter plasmids. After transfection, the cells were incubated in a medium containing Bay 11-7082 $(20 \mu \mathrm{M})$ or LLnL $(20 \mu \mathrm{M})$ for $1 \mathrm{~h}$ and then treated with C. crepidioides $(500 \mu \mathrm{g} / \mathrm{ml})$ for $6 \mathrm{~h}$. Thereafter, luciferase activities were measured. The activities are expressed relative to that of cells transfected with pGL3 iNOS without further treatment, which was defined as 1. LUC, luciferase. Data are mean \pm SD of three independent experiments. (B) RAW264.7 cells were pretreated with Bay 11-7082 $(20 \mu \mathrm{M})$ or LLnL $(10 \mu \mathrm{M})$ for $1 \mathrm{~h}$ before stimulation with C. crepidioides $(500 \mu \mathrm{g} / \mathrm{ml})$ for another $6 \mathrm{~h}$. The iNOS mRNA expression was determined by RT-PCR. (C) RAW264.7 cells were pretreated with the indicated concentrations of Bay 11-7082 or LLnL for $1 \mathrm{~h}$ before stimulation with the indicated concentrations of $C$. crepidioides for another $48 \mathrm{~h}$. The nitrite content in the culture media was analyzed. Data are mean \pm SD of triplicate cultures. C. c., C. crepidioides.

through NO production. These results suggest that $C$. crepidioides is an interesting plant for the development of novel anticancer agents. However, further studies are needed to determine the effects of $C$. crepidioides extract and isochlorogenic acid on tumor growth in patients with malignant tumors.

\section{Conclusions}

We reported in the present study the suppressive effects of C. crepidioides extract on tumor growth in S-180 model through the induction of NO production. Also, the extract stimulated macrophages and induced $\mathrm{NO}$ production via NF- $\mathrm{kB}$ signaling pathway. NO production may play an important role in the antitumor activity of C. crepidioides on S-180 cells. The results suggest that $C$. crepidioides is a potentially useful chemopreventive and chemotherapeutic agent, thus justifying further investigation of other possible beneficial biological properties.

\section{Acknowledgements}

We thank Drs. Kouji Wada and Yoko Aniya for the generous supply of $C$. crepidioides extract and isochlorogenic acid, and for assistance with the preparation of the manuscript. We acknowledge also Drs. Tamara K. Nowling, Dean W. Ballard, Romas Geleziunas and Kuan-Teh Jeang for providing pGL3 iNOS plasmid; for the expression vectors for IKBa- and IKBB-dominantnegative mutants; for NIK-, IKKa- and IKK $\beta$-dominant-negative mutants; and for IKKY-dominant-negative mutant. We also thank Dr. Shigeki Sawada for conducting the pathological examination.

\section{Author details}

'Department of Microbiology and Oncology, Graduate School of Medicine, University of the Ryukyus, 207 Uehara, Nishihara, Okinawa 903-0215, Japan. ${ }^{2}$ Department of Psychiatry, Naha City Hospital, 2-31-1 Furujima Naha, Okinawa 902-8511, Japan. ${ }^{3}$ Musashino Research Institute for Immunity, 790 Nishizatozoe, Gusukube, Miyako Island, Okinawa 906-0106, Japan.

${ }^{4}$ Transdisciplinary Research Organization for Subtropics and Island Studies, 1 Senbaru Nishihara, Okinawa 903-0213, Japan.

\section{Authors' contributions}

KTo designed and carried out the in vitro experiments. SN designed and carried out the in vivo experiments. RK carried out some RT-PCR experiments. $\mathrm{KTa}$ and $\mathrm{Cl}$ made substantial contributions to the in vitro and in vivo experiments. NM conceived the idea, designed and coordinated the study and prepared the manuscript. All authors read and approved the final manuscript.

Received: 8 February 2012 Accepted: 21 June 2012 Published: 21 June 2012 


\section{References}

1. Kongsaeree PK, Prabpai S, Sriubolmas N, Vongvein C, Wiyakrutta S: Antimalarial dihydroisocoumarins produced by Geotrichum sp., an endophytic fungus of Crassocephalum crepidioides. J Nat Prod 2003, 66:709-711.

2. Yen GC, Chen HY, Peng HH: Evaluation of the cytotoxicity, mutagenicity and antimutagenicity of emerging edible plants. Food Chem Toxicol 2001, 39:1045-1053

3. Aniya Y, Koyama T, Miyagi C, Miyahira M, Inomata C, Kinoshita S, Ichiba T: Free radical scavenging and hepatoprotective actions of the medicinal herb, Crassocephalum crepidioides from the Okinawa Islands. Biol Pharm Bull 2005, 28:19-23.

4. Clancy RM, Abramson SB: Nitric oxide: a novel mediator of inflammation. Proc Soc Exp Biol Med 1995, 210:93-101.

5. Ishiyama M, Miyazono Y, Sasamoto K, Ohkura Y, Ueno K: A highly watersoluble disulfonated tetrazolium salt as a chromogenic indicator for NADH as well as cell viability. Talanta 1997, 44:1299-1305.

6. Brockman JA, Scherer DC, McKinsey TA, Hall SM, Qi X, Lee WY, Ballard DW: Coupling of a signal response domain in $\mathrm{IkBa}$ to multiple pathways for NF-KB activation. Mol Cell Biol 1995, 15:2809-2818.

7. McKinsey TA, Brockman JA, Scherer DC, Al-Murrani SW, Green PL, Ballard $D W$ : Inactivation of IkB $\beta$ by the tax protein of human T-cell leukemia virus type 1: a potential mechanism for constitutive induction of NF-KB. Mol Cell Biol 1996, 16:2083-2090.

8. Geleziunas R, Ferrell S, Lin X, Mu Y, Cunningham ET Jr, Grant M, Connelly MA, Hambor JE, Marcu KB, Greene WC: Human T-cell leukemia virus type 1 Tax induction of NF-KB involves activation of the IKB kinase a (IKKa) and IKK $\beta$ cellular kinases. Mol Cell Biol 1998, 18:5157-5165.

9. Iha H, Kibler KV, Yedavalli VRK, Peloponese J-M, Haller K, Miyazato A, Kasai T, Jeang K-T: Segregation of NF-KB activation through NEMO/IKKY by Tax and TNFa: implications for stimulus-specific interruption of oncogenic signaling. Oncogene 2003, 22:8912-8923.

10. Crosby MB, Svenson J, Gilkeson GS, Nowling TK: A novel PPAR response element in the murine iNOS promoter. Mol Immunol 2005, 42:1303-1310

11. Suzuki T, Hirai H, Murakami T, Yoshida M: Tax protein of HTLV-1 destabilizes the complexes of NF-KB and IKB- $\mathrm{a}$ and induces nuclear translocation of NF-KB for transcriptional activation. Oncogene 1995, 10:1199-1207.

12. Antalis TM, Godbolt D: Isolation of intact nuclei from hematopoietic cell types. Nucleic Acids Res 1991, 19:4301.

13. Mori N, Prager D: Transactivation of the interleukin-1a promoter by human T-cell leukemia virus type I and type II Tax proteins. Blood 1996, 87:3410-3417.

14. Sveinbjørnsson B, Olsen R, Seternes OM, Seljelid R: Macrophage cytotoxicity against murine Meth $A$ sarcoma involves nitric oxidemediated apoptosis. Biochem Biophys Res Commun 1996, 223:643-649.

15. Hibbs JB Jr, Taintor RR, Vavrin Z, Rachlin EM: Nitric oxide: a cytotoxic activated macrophage effector molecule. Biochem Biophys Res Commun 1988, 157:87-94

16. Stuehr DJ, Nathan CF: Nitric oxide. A macrophage product responsible for cytostasis and respiratory inhibition in tumor target cells. J Exp Med 1989, 169:1543-1555.

17. Nathan C, Xie Q-W: Nitric oxide synthases: roles, tolls, and controls. Cell 1994, 78:915-918.

18. Xie Q-W, Kashiwabara Y, Nathan C: Role of transcription factor NF-KB/Rel in induction of nitric oxide synthase. J Biol Chem 1994, 269:4705-4708.

19. Lowenstein CJ, Alley EW, Raval P, Snowman AM, Snyder SH, Russell SW, Murphy WJ: Macrophage nitric oxide synthase gene: two upstream regions mediate induction by interferon $\gamma$ and lipopolysaccharide. Proc Natl Acad Sci USA 1993, 90:9730-9734

20. Goldring CEP, Narayanan R, Lagadec P, Jeannin J-F: Transcriptional inhibition of the inducible nitric oxide synthase gene by competitive binding of NF-KB/Rel proteins. Biochem Biophys Res Commun 1995, 209:73-79.

21. Kim YM, Paik S-G: Induction of expression of inducible nitric oxide synthase by Taxol in murine macrophage cells. Biochem Biophys Res Commun 2005, 326:410-416.

22. Karin $\mathrm{M}$, Ben-Neriah Y: Phosphorylation meets ubiquitination: the control of NF-KB activity. Annu Review Immunol 2000, 18:621-663.
23. Malinin NL, Boldin MP, Kovalenko AV, Wallach D: MAP3K-related kinase involved in NF-KB induction by TNF, CD95 and IL-1. Nature 1997, 385:540-544.

24. Pierce JW, Schoenleber R, Jesmok G, Best J, Moore SA, Collins T, Gerritsen ME: Novel inhibitors of cytokine-induced IkBa phosphorylation and endothelial cell adhesion molecule expression show anti-inflammatory effects in vivo. J Biol Chem 1997, 272:21096-21103.

25. Jeremias I, Kupatt C, Baumann B, Herr I, Wirth T, Debatin KM: Inhibition of nuclear factor $\mathrm{KB}$ activation attenuates apoptosis resistance in lymphoid cells. Blood 1998, 91:4624-4631.

26. Lancaster JR Jr, Hibbs JB Jr: EPR demonstration of iron-nitrosyl complex formation by cytotoxic activated macrophages. Proc Natl Acad Sci USA 1990, 87:1223-1227.

27. Martin E, Nathan C, Xie Q-W: Role of interferon regulatory factor 1 in induction of nitric oxide synthase. J Exp Med 1994, 180:977-984.

28. Gao J, Morrison DC, Parmely TJ, Russell SW, Murphy WJ: An interferon-ץactivated site (GAS) is necessary for full expression of the mouse iNOS gene in response to interferon- $\gamma$ and lipopolysaccharide. J Biol Chem 1997, 272:1226-1230

29. Sawada T, Falk LA, Rao P, Murphy WJ, Pluznik DH: IL-6 induction of protein-DNA complexes via a novel regulatory region of the inducible nitric oxide synthase gene promoter: role of octamer binding proteins. J Immunol 1997, 158:5267-5276.

30. Kim YM, Ko CB, Park YP, Kim YJ, Paik SG: Octamer motif is required for the $\mathrm{NF}-\mathrm{KB}$-mediated induction of the inducible nitric oxide synthase gene expression in RAW 264.7 macrophages. Mol Cells 1999, 9:99-109.

31. Murakami A, Ohigashi H: Targeting NOX, INOS and COX-2 in inflammatory cells: chemoprevention using food phytochemicals. Int J Cancer 1999, 121:2357-2363.

32. Ortega MG, Saragusti AC, Cabrera JL, Chiabrando GA: Quercetin tetraacetyl derivative inhibits LPS-induced nitric oxide synthase (iNOS) expression in J774A.1 cells. Arch Biochem Biophys 2010, 498:105-110

33. Hämäläinen M, Nieminen R, Vuorela P, Heinonen M, Moilanen E: Antiinflammatory effects of flavonoids: genistein, kaempferol, quercetin, and daidzein inhibit STAT-1 and NF-KB activations, whereas flavone, isorhamnetin, naringenin, and pelargonidin inhibit only NF-KB activation along with their inhibitory effect on iNOS expression and NO production in activated macrophages. Mediators Inflamm 2007, 2007:45673.

doi:10.1186/1472-6882-12-78

Cite this article as: Tomimori et al:: Antitumor activity and macrophage nitric oxide producing action of medicinal herb, Crassocephalum crepidioides. BMC Complementary and Alternative Medicine 2012 12:78.

\section{Submit your next manuscript to BioMed Central and take full advantage of:}

- Convenient online submission

- Thorough peer review

- No space constraints or color figure charges

- Immediate publication on acceptance

- Inclusion in PubMed, CAS, Scopus and Google Scholar

- Research which is freely available for redistribution 